https://doi.org/10.48009/2_iis_2007_468-472

\title{
Help Desk Renaissance: A New Understanding of the Importance of Technical Support Services
}

\author{
Wayne M. Machuca, Mt Hood Community College, machucaw@mhcc.edu
}

\begin{abstract}
The technical help desk has traditionally been a place where minimal effort or expense is placed. To save money, many companies have sent their call centers overseas. However, new issues are developing which are causing companies to rethink their technical support strategy. These issues include (1) an increase in technological frustration by American consumers, (2) a back lash of American consumers against companies using foreign call centers, (3) a reduction of experienced workers as the "baby boomers" retire, and (4) an insufficient number of new IT college graduates able to fill the void. The implication is that the combination of these forces is creating a "perfect storm" which will ultimately affect information systems in two ways. First, it will force companies to rethink their IT support programs and require an increased investment in technical services as well as payroll. Second, it will force academia to give credence to and create curriculum for general technical programs as the demand for such graduates increases. This paper is an examination of the impact of these forces and details how to deal with the need to provide effective technical support.
\end{abstract}

Keywords: Information Technology (IT), Help desk, Technical support, careers.

\section{INTRODUCTION}

By the mid-2000's, several contrasting factors have come together which are of critical importance to the CIS industry and training programs alike. First is the increasing complexity of technology [1]. From systems and networks to consumable electronics, technological products are requiring consumers to have more tech sophistication and not less [2]. This leads to, second, customer/user interaction with technical support services or the help desk. Contacts to the call center are often the only human interaction users have with an organization. Unfortunately, third, in an effort to save money, many organizations have moved their call centers off-shore [3]. This movement created a perception of the lack of CS/IS opportunities across the spectrum and led to, fourth, a significant and dramatic decrease in enrollments for technical programs nationally.
Meanwhile, a growing frustration with foreign call centers (on both sides of the issue) is creating a consumer backlash that is driving organizations to bring their call centers back on-shore. Coincident is the reduction of qualified technicians in the workforce as the "baby boomers" begin to retire. Unfortunately, with lower enrollments comes less graduates; and now, fifth, the demand for entry-level technical personnel vastly exceeds the supply.

This paper is an examination of the aforementioned issues and describes how industry and academia can facilitate the need for entry-level technical workers.

\section{The Impact of the Decrease in CS/IS Enrollments}

One interesting phenomena of the past half decade has been the significant drop in enrollments in college and university Computer Science (CS) and Information Systems (IS) programs [4, 5, 6]. Schools across the nation are reporting huge reductions in enrollments. UCLA notes that IT enrollments are off an incredible 93\% [7]. Reasons for this decline vary. Some argue that the decrease is due mainly to the publicity surrounding out-sourcing or off-shoring the option of moving low skilled technical positions to low paid technical workers overseas $[8,9,10]$. That perspective is not unsubstantiated. Hoffman \& Thibodeau [11] quotes John C. McCarthy that "By 2015, 3.3 million white-collar jobs - 472,632 of them in IT and mathematics - and $\$ 136$ billion in wages are expected to move offshore to countries like Russia, India, China and the Philippines...” Whatever the reason, there is clearly a frustrating shortage of entry-level technical workers in the US. [12].

What makes this matter particularly troubling is that all indications foresee a significant increase in the need for technical workers well into the 2010's and very likely into the 2020's. The Bureau of Labor Statistics [13] reports that of the top 20 careers for the next ten years, five are computer technical related (network analysts, applications software, systems software, network administrators, and data base administrators), many of which will have significant spin-off careers [14]. Of the remainder, the majority are medical careers which themselves have 
significant technological infusion. Based on current trends, in the next ten years there will be twice as many technical entry level career position as their will be technical graduates to fill those positions [15]. As the demand for skilled technical workers increases and the supply of the same continues to diminish, the value, and by extension, the price, of technical workers will increase dramatically.

\section{Aging Workforce Enhances the Shortage}

January 1, 2006 was observed as the " $60^{\text {th }}$ Birthday" for a demographic known as the "baby boomers". This group of people generally acknowledged as being born between the end of World War II and 1960 constitutes a significant portion of the US workforce and economy. Over the next 5 to 10 years, this large group will begin to dissipate out of the workforce. With them goes a significant amount experience, knowledge, and wisdom which companies are struggling to capture through the use of expert systems and knowledge management.

Regarding this preservation, Hoffman, T. [16] quotes Harriet Edleman of Avon Products Inc. in New York, "We're trying to preserve the internal knowledge that's important to the business while leveraging lower labor rates and technological sophistication in different geographies.” Cost savings are an important issue to corporations. One money-saving technique is to capture knowledge through the use of knowledge management software. Though powerful and helpful, even the best knowledge management tools can only predict trends. They do not learn. If the problem was solved before, that solution will be applied to future occurrences of similar problems.

\section{The Customer's First Point of Contact}

When a problem arises with a piece of technology, the customer's first (and usually only) point of contact with the company is the help desk. Whether frivolous or complicated, the customer will bring their problem to technical support and expect a solution. It is the responsibility of the help desk worker to well represent the organization. The help desk worker must then possess not only technical skills, but also be dynamic, creative, pleasant, and caring. They must be able to listen like an emergency room doctor: ask the right questions and develop an accurate diagnosis [17]. They must be a sort of "technical geek" and "people person” rolled into one. The web site HelpDeskSoftware.cc [18] notes,

"In today's business world, help desks have become a crucial part of a businesses service function. In many cases, the help desk creates an image and represents a company in the eyes of its customers. The importance of the help desk function in any organization should not be under estimated."

As a matter of efficiency, many organizations will strive to be able to solve a customer's problem on first contact [19, 20, 21].

\section{Searching for a Cost-Saving Solution}

In many technology development companies, there exists the opinion that the greater share of the investment must be with the developers. It is the developers who create the products and these developers must be cared for. On the other hand, in order to maximize the amount of investment available for the developers, other departments must be scaled back. Many organizations have chosen to move their help desks and call centers overseas. Typically, call centers are being moved to India, Pakistan, Israel, and Central and South America. In these areas, foreign trained technical people will work for a fraction of their US counterparts and are typically willing to read common solutions from technical "scripts” [22, 23].

Though once an interesting idea, the use of foreignbased call centers has become a standing joke in information technology circles. US consumer attitudes are beginning to back-lash against the call centers specifically and the companies in general. It is now common for foreign call center workers to suffer verbal abuse, racial slurs, and searing anger $[24,25]$. And yet, many leading managers still view the development of the help desk as laughable [26].

\section{Deflecting the "Perfect Storm"}

As computer technology moves into the last half of this decade, several significant events are converging to produce a "perfect storm" [27]. Because of the perception of the relocation of IT jobs overseas, many believe that there is no future in a technical degree. As a result, very few people are attracted to technical training programs. With fewer new technical students, there are even fewer new graduates. While in reality over the next 10 years there will be a significant increase in entry-level technical positions, there will be very few people who will be available to fill those positions. The pressure to attract new workers will be increased as baby boomers retire or leave the organization taking their combined knowledge and wisdom with them. 
Meanwhile, the increasing complexity of technology is requiring users to have an even greater level of computer sophistication in order to function. However, users are proving themselves resistant to learning the new technology which has led to increased frustration which results in functioning products returned and increased calls to the help desk.

The bottom line is that in an effort to save money, companies have shipped many support positions overseas where the wages are lower. Consumers, already frustrated with a "non-functioning" piece of technology, often see the foreign call center worker as an opportunity to vent their frustration at a helpless target. In the end, the call center workers are unhappy, the company is unhappy and the customer is unhappy. Customers are beginning to lash back at companies who use cut rate foreign workers in their call centers. In some cases, the back lash is so severe that companies are abandoning their overseas centers and returning them state side [28].

To find the solution, IT must first reexamine the help desk: the company's point of contact with its customer-base. Lovelace [29] notes that one of the primary problems in working with changing the help desk is that the majority of the IT investment, as well as the superstars, go to development. He continues that "no self-respecting Human Resources person would approve salaries aimed at attracting and keeping competent help-desk employees”. Entrylevel workers still have a home at the help desk. While a good place to allow workers to get initiated in learning the product, these workers also need superstars to back them up in the event of an escalation.

Nevertheless, dynamic, interactive superstars are exactly what are needed at that point of contact. Customers calling in need to know (or be able to sense) up front that the person with which they are dealing is knowledgeable, understanding, and approachable. Many people are reluctant to share all of the facts out of embarrassment. The help desk superstar must be able to weed out the relevant information, or be able to create the affinity that would permit the user to volunteer that information [30].

Help desks and call centers tend to have similar needs and issues. A university help desk is no exception. Edge [31] notes "Higher education leaders are increasingly looking to IT departments to solve problems and be the strong force behind changes. In the EDUCAUSE annual research on current IT issues within higher education, strategic planning for IT ranked fourth.” The solution is to keep help desk personnel available and relevant. Edge [32] concludes, "In the end, it is the constituents that will ultimately benefit from effective strategic planning, reaching the ultimate goal of a higher education; then, in turn, educating their posterity.”

\section{RECOMMENDATIONS}

The CIS community can well satisfy the changing needs of the market place by advocating specific enhancements in industry and academia. These include, but are not limited to, the areas of staff training, user training, payroll structure review, and college curricula.

\section{Staff training}

Training for the technical staff is typically weak. Full time workers can participate in some seminars and receive periodicals. Part time worker receive only "on the job" training. Some types of training materials are available for free over the internet including web blogs, emails, web casts and others. There is a certain cost saving advantage to utilizing the free training tools. Often due to size limitations, these can provide quick solutions to common problems [33].

\section{User Training}

In his list of the five most important applications in overall strategy, Yudkowsky [34] identifies user self service as one of the five. The user community needs to be trained so that they actually can be their own first contact for their own problems. Yudkowsky advocates availability of a knowledgebase resource. The concept is to provide the tools so that users have an opportunity to help themselves before making the call. A simple list of trouble shooting questions can often prevent an "unnecessary" call. For example, if a printer is not functioning, rather than calling in, even the moderately sophisticated user can do some diagnostics. A simple list with questions such as (1) is the printer plugged in? and (2) do you see lights on the printer? would assist the user in solving their own problem or in making a more informed call if necessary. The St. Norbet College web site [35] contains an excellent example of diagnostic questions the user can ask before calling the help desk.

\section{Pay Structure Review}

As the demand for entry level technical workers increases and the supply of the same decreases, their 
value, especially in the local metropolitan market will be greatly enhanced. With enticements and higher wage availability in metropolitan regions, technical workers will start to find it easier to change jobs with a significant pay increase. Recognizing this, company administrators must consider seriously pay increases for technical support or risk losing their most talented technicians and become even more dependant on under skilled and temporary student workers.

\section{College Curricula}

As career opportunities for general technical graduates increase, the demand for relevant course work will also increase. Students and companies will seek out technical training programs less for their theoretical and esoteric classes and more for their relevance and practicality. Colleges will well serve their students, and by extension increase enrollments, by providing a portion of their coursework directly applicable to their local general technological market.

\section{CONCLUSIONS}

Owing to dramatic changes in the availability and use of technologies, the computer industry is changing. In Information Systems, the need for pure programmers has matured and worker demand is distributed across the technology spectrum. One quickly growing area of interest is with the general IT graduate. Companies are starting to learn that the lowly help desk, once the scourge of IT departments, is quickly becoming an important function as it is typically the only point of contact between the company and its customers. This is becoming especially important as technology increases in complexity and users are becoming increasingly frustrated with that complexity. To take this critical point of contact and farm it overseas to call centers staffed with poorly paid and disrespected workers with little investment in the success of the organization may have once been considered a shrewd competitive decision, it is now apparent that savings were never worth the injury suffered from customer backlash.

Now it is clear that the help desk is becoming a critical function in the overall computer services infrastructure. Companies should acquire more sophisticated tracking software which would allow them to preempt problems before they occur. Increased training and increased salaries would attract quality technicians and keep good workers from leaving. Self support and FAQ web sites providing simple instructions and training for the user community should be developed to help users to help themselves first before contacting the call center. Policies and procedures strengthening the functionality of the help desk as an important department must be developed which would give the help desk responsibility for its production as well as authority to direct its own actions.

\section{REFERENCES}

1. Complexity Causes 50\% of Product Returns: Scientist. (2006, March 6). Retrieved on November 14, 2006 from the RedOrbit Web site at

http://www.redorbit.com/news/technology/41741 4/complexity_causes_50_of_product_returns_sci entist/index.html.

2. Complexity Causes $50 \%$ of Product Returns: Scientist. (2006)

3. Pallato, J. (2006, May 19). IT managers see no end in site to technology complexity. Retrieved November 14, 2006 from the eWeek Web site at http://www.eweek.com/article2/0,1759,1817534, 00.asp?kc=EWRSS03119TX1K0000594

4. Montalbano, E. (2005, July 18). Gates worried over decline in U.S. computer scientists. Retrieved on July 19, 2005 from the Computerworld website at http://www.computerworld.com/careertopics/car eers/story/0,10801,103313,00.html?SKC=careers $-103313$

5. Tucci, L. (2005, June 8). College students continue to shun computer science. Retrieved on March 15, 2006 from the SearchCIO.com Web site

at http://searchcio.techtarget.com/originalContent/0 ,289142,sid19 gci1096260,00.html

6. Anderson, C.A. (2003, February 24). Computer classes see dipping enrollments. The Harvard Crimson, Online Edition. Retrieved on March 15, 2006 from http://www.thecrimson.com/article.aspx?ref=274 $\underline{172}$

7. Lennox, T.L., Woratschek, C.R., Davis, G.A. (2005, October 8). Exploring declining CS/IS Enrollments. ISECON 2005, v22. Retrieved on November 14, 2006 from the Information Systems Education Journal Web site at http://isedj.org/isecon/2005/3124/ISECON.2005. Lenox.pdf

8. Weiss, T.H. (2005, July 15). Tech jobs show Q2 dip, study says. Retrieved on July 19, 2005 from the Computerworld website at http://www.computerworld.com/careertopics/car 
eers/labor/story/0,10801,103228,00.html?SKC=c areers-103228

9. Hoffman, A. (2005a). CIOs on offshoring. Retrieved on July 19, 2005 from the Monster website at http://technology.monster.com/articles/offshore/

10. Hoffman, A. (2005b). Surviving offshoring. Retrieved on July 19, 2005 from the Monster website

at http://technology.monster.com/articles/offshorew ork/

11. Hoffman, T. \& Thibodeau, P. (2003, April 29). Exporting IT Jobs. Computerworld, v37 17. 3942.

12. Taft, D.K. (2005, July 19). Gates: lack of computer spending is 'kind of a crime'. Retrieved from the eWeek.com Web site at http://www.eweek.com/article2/0,1895,1838435, 00.asp

13. Tomorrow's Jobs. (2004, June 2). Retrieved on July 19, 2005 from the U.S. Bureau of Labor Statistics website at http://www.bls.gov/oco/oco2003.htm

14. Stooker, R. (2005). Discover the 8 reasons why now is the best time every to change to a computer career. Retrieved on July 19, 2005 from http://www.inforingpress.com/

15. Venator, J. (2006, July 10). "Perfect storm" on horizon for U.S. labor market. Retrieved on July 11, 2006 from the ComputerWorld Web site at http://www.computerworld.com/action/article.do ?command=viewArticleBasic \&articleId=900167 $\underline{1}$

16. Hoffman, T. (2003).

17. Melymuka, K. (2005, January 24). IT Emergency Room. Computerworld, v39, 4. 36.

18. Help Desk Software (2004). Retrieved on November 14, 2006 from the help desk software Web site at http://www.helpdesksoftware.cc/

19. ISS help desk mission. (2006, March 13). Retrieved on November 14, 2006 from the George Washington University Web site at http://helpdesk.gwu.edu/policies/mission.html

20. Blake, D. (2002, January). BIS help desk services expanded. Retrieved from the State of Maine Web site

at http://www.state.me.us/newsletter/jan2002/bis_h elp_desk_services_expanded.htm

21. Help desk introduction guide. (2002). nanoDesk Technologies. Retrieved on November 14, 2006 from the helpdesk.com Web site at http://www.helpdesk.com/hdintrobooklet.doc

22. McDougall, P. (2005, October 10). Indian call centers may no longer be worth the trouble. Retrieved on November 16, 2006 from the InformationWeek web site at http://www.informationweek.com/blog/main/arc hives/2005/10/indian_call_cen.html

23. Indian call centers may no longer be worth the trouble. (2005, October 10). Abstract. Retrieved on November 16, 2006 from the InformationWeek Web site at http://www.itbusinessedge.com/item/?ci=7730

24. McPhate, M. (2005, November 17). Outsourcing outrage Indian call-center workers suffer abuse. Retrieved on November 14, 2006 from the San Francisco Chronicle Web site at http://www.sfgate.com/cgibin/article.cgi?f=/c/a/2005/11/17/BUGB3FPGT0 1.DTL

25. Engardio, P. (2006, April 10). Making Bangalore sound like Boston. Retrieved on November 16, 2006 from the InformationWeek web site at http://businessweek.com/magazine/content/06_1 5/b3979081.htm

26. Lovelace, H. W. (2004, July 12). Superior IT Service? Get Help-Desk Superstars. Informationweek, v997. 64.

27. Venator, J. (2006).

28. Kurtz, R. (2004, July). The Problem: Angry customers. Language Issues. Phone static. Maybe outsourcing the help desk wasn't such a great idea after all. Inc. Magazine, v26, 7. 48-49.

29. Lovelace, H. W. (2004).

30. Yudkowsky, C. (2006, February). Creating a successful help desk environment. Retrieved on November 2, 2006 from the SmartPros Web site at http://accounting.smartpros.com/x51141.xml

31. Edge, J. W. (2004, October). The Need for Strategic Planning in Academia. T.H.E. Journal, v32, 3. 40.

32. Edge, J. W. (2004).

33. Bass, S. (2003, July). Helpfulness Is Next to Geekliness. PCWorld, v21, 6. 57.

34. Yudkowsky, C. (2006).

35. Help Desk. (2006). Retrieved on November 16, 2006 from the St. Norbert College Web site at http://www.snc.edu/compserv/helpdesk/ 